\title{
Entrepreneurs' Resilience Measurement
}

\author{
Nor Aishah Buang \\ Universiti Kebangsaan \\ Malaysia
}

\section{Introduction}

Since independence, the Malaysian government had appointed several agencies to assist her in increasing the number of entrepreneurs. These agencies had produced quite a significant number of business start-ups from various backgrounds and products. However, the concern was on the number of success rate that these agencies can produce in terms of sustainable and successful entrepreneurs. Based on the current sources of data, the success rate for the start-ups to sustain was constantly below four per cent (MDeC 2008). The next question was how can these agencies able to detect at the early stages those new entrepreneurs who have the potentials to drop out. Thus, the author developed an instrument for measuring the psychological side of resilience index of these entrepreneurs. This index will help the agencies to take some measures to assistthe new start-ups sustain their business.Before this effort, those agencies hadbeen monitoring these new start-up or entrepreneurs' development based on the figures of their business performances such as profits, turnovers, sales rather than on their resilience level such as self-strengths, cognitive strengths and social networking skills.

Thus, the purpose of this chapter is to describe how the writer developed an entrepreneurship resilience instrument which can be used to measure the level of resilience of newly developed entrepreneurs. This level of resilience can be measured in the form of certain index. Based on this index, certain early measures or interventions can be taken to help the sustainability of the entrepreneurs' business. In summary, the chapter will describe how the concept of resilience was determined in the context of its constructs and contents to be measured, how the first draft of the entrepreneur resilience instrument based on the above concept was designed, how the content validity of the draft entrepreneur resilience instrument was determined, how the face validity of the draft entrepreneur resilience instrument was determined, how the items' reliability of the draft entrepreneur resilience instrument was determined, determination of consistency in terms of the items' reliability through test-retest (standardization) process, factorial analysis procedure and interpretation of the index level of entrepreneurs resilience.

\section{Developing the concept of resilience}

The first step was to define the concept of resilience in the context of entrepreneurship based on literature reviews. The author found thatthere was no specific terms such as entrepreneurial resilience at that time except for the term 'business resilience' which was 
measured in terms of 'business organizations' performance' such as the amount of sales, income and revenue. The word 'emotional resilience' was found not suitable to be used because it is a common term being largely used in the discipline of psychology and focusing only on one dimension only. The word 'business resilience' was also not suitable to be used because it focuses on the organization itself rather than the human beings. The word 'social resilience' was also not suitable because it's a term commonly used in sociology and anthropology to refer to the survival of a community in a population within a certain physical environment.

The term resilience had slowly developed based on the following events:

- Resilience emerged as a major theoretical and research topic from the studies of children of schizophrenic mothers in the 1980s (Luthar, Cicchetti, \& Becker, 2000; Masten, Best, \&Garmezy, 1990).

- Emmy Werner (1980) was one of the first scientists to use the term resilience. She studied a cohort of children from Kauai (Hawaiian Islands). Kauai was quite poor and many of the children in the study grew up with alcoholic or mentally ill parents.

- In psychology, resilience refers to the positive capacity of people to cope with stress and catastrophe. It is also used to indicate a characteristic of resistance to future negative events.

- At work place, resilience means the act of resolving conflicts, turn disruptive changes into new directions, learn from this process, and become more successful and satisfied in the process (hardiness).

- In this sense "resilience" corresponds to cumulative "protective factors" and is used in opposition to cumulative "risk factors". The phrase "risk and resilience"' in this area of study is quite common.

- Commonly used terms, which are essentially synonymous within psychology are "psychological resilience", "emotional resilience", "hardiness", and "resourcefulness".

- Resilient children and their families had traits that made them different from nonresilient children and families.

- Resilience can be described by viewing: (1) good outcomes regardless of high-risk status, (2) constant competence under stress, and (3) recovery from trauma(Masten, 1989).

- $\quad$ Resilient people are expected to adapt successfully even though they experience risk factors that are against good development. Risk factors are related to poor or negative outcomes.

- Finally, resilience can be viewed as the phenomenon of recovery from a prolonged or severe adversity, or from an immediate danger or stress (Carver \&Scheier, 1999; Davidson, 2000).

- In this case, resilience is not related to vulnerability

The author then synthesized the concept of entrepreneur resilience from the psychology school of thought and applied it in business management contexts. Based on several references of the meaning of resiliencein general and related readings of how successful entrepreneurs overcome their business challenges, the author concludes that entrepreneurship resilience means 1) the ability to cope well with high levels of on-going disruptive change of the surroundings towards their business; 2) sustain good health and energy when under constant pressure of various business problems; 3) bounce back the 
business with acceptable means from setbacks; 4) overcome business adversities; 5) change to a new way of working and managing the business when the other way is no longer possible and do all this without acting in dysfunctional or harmful ways.

\section{Developing the first draft of the entrepreneur resilience instrument}

Having definedthe construct 'entrepreneur resilience', the first step in developing the instrument was to do a thorough literature review search on its sub-construct. For each of the sub-constructs, the author determined their concepts which were then used as the content of each items in the instrument. To further validate the determination of these subconstructs and concepts and also the items' contents of the draft resilience instrument, the author confirmed some of them with the qualitative data collected from the interviews with twenty real new entrepreneurs or start-ups that had been in business between three to five years. . The framework for the approach of this instrument was determined based on universal input-process-output model. Finally, the 'feel' of the items in the instrument was written based on how the entrepreneurs use their resilience strengths in facing their business problem situations.

Based on the reading evidences, the author concluded that entrepreneur resilience can be described by three different components pertaining to a complete human development such as

1. Self (internal strengths)

2. Business situational-cognitive abilities (cognitive competence)

3. Business social-relational abilities (social competence)

'Self' can be referred to five different dimensions such as emotional strength, mental strength, physical strength, spiritual strength and moral stand. Business-situational cognitive abilities can be referred to i. have meta-cognitive capacity to plan, monitor and evaluate own activities, ii) critical thinking competences applied to business situationsproblem solving skills, decision making skills, conceptualizing skills, logical reasoning, evaluating, judgment, analysing, inferring, questioning, perceiving, prioritizing, patterning, conceiving etc., iii) creative thinking competences applied to business situations-idea collecting, visualizing, making analogies, ideas designing, predicting trend, intellectual guessing, hypothesizing, discovering attitudes, look for alternatives, innovative. Finally, business social-relational abilities can be referred to i) Ability to form secure attachments, ii) basic thrust of partners/workers, iii) ability and opportunity to actively seek help from others, viability to make and keep good friends, iv) ability to empathize, v) possess goodother awareness, vi) possess good communication skills and vii) being open to a variety of ideas and points of view

\section{Theory underlying the concept of entrepreneur resilience}

The basic model used in this research was based on the Successful Start-up Business Model proposed by Baron, Frese and Baum (2007) in the The Psychology of Entrepreneurship book. This model combines an entrepreneur's factors such as his or her own personality, his own human capital and his psychological capital which are needed for him or her to start a business. These three factors then contribute to four main elements for success such as the state of his or her psychology, cognition, action and social capital which are the main 
ingredients for producing resiliency and drive entrepreneurs to start a business and sustain it after that. In short, Baron, Fresedan Baum emphasized that there is a relationship between entrepreneur and psychological, cognition and social factors in determining the success of a business.

This model pointed out that for an entrepreneur to be successful in starting a business, it depends on two main foundations. They are the basic foundation and the proximal foundation. The basic foundation consists of four factors such as the entrepreneur's personality (characteristics and capabilities), his or her psychological capital (optimist, perseverance and fitness), human capital (expertise, experience, education, knowledge and skills) and social capital (networking and relationships). These four factors then contribute to the outcomes of the proximal foundations which has four main elements for success such as the internal state of psychology, cognition (such as competence and problem-solving) and finally the action process. All these three elements then contribute to the outcome of resilience, self-efficacy and hopes in the entrepreneur. This state of resilience, self-efficacy and hopes then drives the success of starting a business. This model is depicted in the diagram below:

\section{Basic Foundations Proximal Foundations}

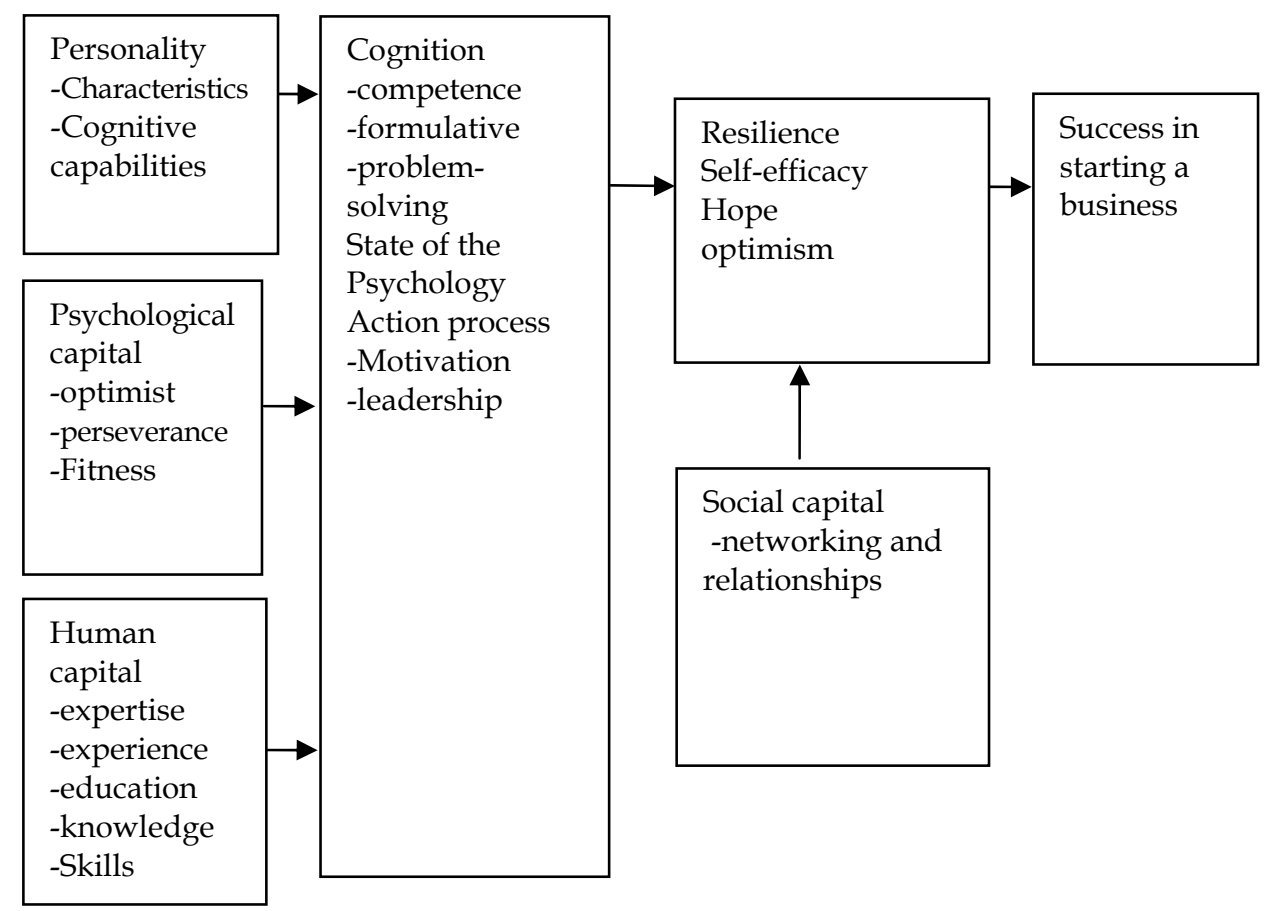

Sources: Baron, Fresedan Baum (2007); Brooke (2004) ;Luthans (2004, 2007)

Fig. 1. Successful Start-up Business Model from the human side 
Brooke (2004) who is also in agreement with Baron, Fresedan Baum (2007) adds financial capital to the already four factors proposed by them. Luthans (2004) further expands the criteria or the outcomes of the psychological capital such as self-efficacy, hopes, optimism and resilience. According to him, an entrepreneur should put a high hope and confidence with the knowledge, skills and capabilities he or she has in starting a business. An entrepreneur also has to be optimistic so that whatever problems he or she encounters are treated as temporary and thus trying to overcome those problems. He further added that an entrepreneur must be resilient as a preparation to face business problems and difficult situations. In short, the four capital of the human side of the entrepreneurs play a vital role in ensuring the success and sustainability of a business. In another study conducted by Nandram and Samsom (2006) on more than sixty entrepreneurs in Europe also found the important role of the human factors a) for explaining venture performance or start-up, b) in describing the development of firms and finally c) explaining venture failures. They proposed Strategic Management model which also support Baron, Fresedan Baum (2007)'s model in terms of the human factors that contribute to the success of a business start-ups. Based on the above definition of resilience, the format and the corresponding references of the constructs and sub-constructs of resilience from the literature review, the first draft of the instrument was built. This first draft was then polished through several processes of amendments and items' reliability and validity. Each of the items in each section has its negative match except for the outcomes section. The purpose was to prepare for measuring the non-resilience level of a respondent other than acting as a check and balance throughout the instrument.

\section{Managing the content validity}

The purpose of this phase was to get the agreements of the entrepreneurship experts and some entrepreneurs on the concept, constructs and content of the items selected in the draft resilience instrument. This phase was necessary as part of the instrument development procedure for ensuring its content validity. A one day workshop was conducted which involved six entrepreneurship professors from local universities, seven entrepreneurs and entrepreneurship development staffs and a few facilitators who were PhD students in Entrepreneurship and Business Education from the local universities. Most of the comments were on the technical aspects of the draft instrument such as the number of items, sentence structure and length and the use of Likert scales. Overall, the constructs and the content of the items were agreed upon with some suggestions of rewording the sentences.

\section{Managing the face validity}

Face validity is a necessary procedure in any instrument development process (Benson \& Clark 1983). The purpose is to check whether the items can be understood easily and similarly by any respondent. This session was conducted with several new entrepreneurs from various business types. The researcher presented to the new entrepreneurs the underlying framework for the development of the instrument in terms of the overall approach such as the input-process-output format. The orientation of writing the items based on how an entrepreneur uses his or her internal strengths and cognition to manage his or her business problems in a certain business context. Finally, the construction of the items based on the concepts of the constructs and sub-constructs based on the literature 
review search and interviews data with the entrepreneur. In terms of the number of items, the entrepreneurs were told that at this stage the number of items weredecided based on the saturated number of contents found in the literature review. The number of items had to be determined by the item reliability and factorial analysis test in the later stage. All the new entrepreneurs tried to respond to the items in the draft instrument. Most of them took more than 45 minutes to finish it. However, one of them managed to finish responding to the items in 20 minutes. In terms of the items' sentences, they informed a number of items that they did not understand and need to be rewritten including the sentence grammatical errors. The author then looked into those sentences that cannot be understood either readily or easily and reword them. At this stage, the items in the instrument had been reworded many times from long sentences to short sentences while ensuring the meanings did not changed.

\section{Managing the items'reliability}

The next necessary procedure in any instrument development process is to determine the items' reliability. The purpose of this procedure was to determine which items should be retained and which items should be dropped based on the values of the Cronbach Alpha (Creswell, 2008; Gall and Gall, 1998). There were three stages of development for this purpose. First, the draft instrument with 204 items was piloted with thirty respondents (both the one with 4 Likert scales and 5 Likert scales). Second, based on the Cronbach Alpha values of each items in both of the draft instruments with 204 items which were less than 0.5 , some items were dropped which left the instruments with only 151 items. Third, the draft instrument with 5 Likert scales were chosen because the Cronbach Alpha values were better than the one with 4 Likert scales. This newer draft instrument with 151 items were tested on five different groups of samples for the purpose of standardization.

\section{Managing the standardization process}

For this phase, five different groups of new entrepreneurs were administered with the draft instrument of 151 items and 5 likert scales. This process is called standardization. The purpose was to ensure that the same instrument when administered on the different groups of entrepreneurs (from different places and backgrounds), the Cronbach Alpha values of the items remained almost the same. This means that this instrument is highly reliable to be used on any group of the new entrepreneurs population. Table 1 shows that the values of the Cronbach alpha of the constructs for the five different groups when compared were more or less the same.

\section{Factorial analysis procedure}

The final phase of this process of developing the entrepreneur resilience instrument was to run the factorial analysis procedure on the draft instrument with 151 items and 5 Likert scales. The purpose of doing factorial analysis was to determine whether the items for each construct truly belong to them or in other words whether the items measure the constructs. This procedure informs which items should be rejected or retained under one construct. It works by calculating the correlational values between the items within the given constructs 


\begin{tabular}{|l|l|c|c|c|c|c|c|}
\hline & Constructs & $\begin{array}{l}\text { CronbachAlpha } \\
\text { (5 Likert Scales) }\end{array}$ & $\begin{array}{c}\text { Group 1 } \\
\mathrm{N}=\mathbf{3 0}\end{array}$ & $\begin{array}{c}\text { Group 2 } \\
\mathrm{N}=30\end{array}$ & $\begin{array}{c}\text { Group 3 } \\
\mathrm{N}=30\end{array}$ & $\begin{array}{c}\text { Group 4 } \\
\mathrm{N}=43\end{array}$ & $\begin{array}{c}\text { Total } \\
\mathbf{N}=\mathbf{1 3 3}\end{array}$ \\
\hline 1 & $\begin{array}{l}\text { Optimistic } \\
\text { (item P\&N) } \\
\text { n item=24 }\end{array}$ & 0.7318 & $\mathbf{0 . 8 1 8 2}$ & $\mathbf{0 . 7 4 9 7}$ & $\mathbf{0 . 7 4 2 5}$ & $\mathbf{0 . 8 0 8 3}$ & $\mathbf{0 . 7 8 8 6}$ \\
\hline 2 & $\begin{array}{l}\text { Perseverance } \\
\text { (item P\&N) n=16 }\end{array}$ & 0.6164 & $\mathbf{0 . 5 5 9 6}$ & $\mathbf{0 . 5 3 4 3}$ & $\mathbf{0 . 6 9 7 7}$ & $\mathbf{0 . 6 6 0 1}$ & $\mathbf{0 . 6 3 0 2}$ \\
\hline 3 & $\begin{array}{l}\text { Fitness (item } \\
\text { P\&N) n=26 }\end{array}$ & 0.5133 & $\mathbf{0 . 7 9 8 4}$ & $\mathbf{0 . 6 6 9 7}$ & $\mathbf{0 . 7 0 2 9}$ & $\mathbf{0 . 7 2 9 7}$ & $\mathbf{0 . 7 2 2 8}$ \\
\hline 4 & $\begin{array}{l}\text { Competences } \\
\text { (item P\&N) n=14 }\end{array}$ & 0.6985 & $\mathbf{0 . 6 4 9 1}$ & $\mathbf{0 . 5 1 9 7}$ & $\mathbf{0 . 7 0 7 7}$ & $\mathbf{0 . 2 1 0 4}$ & $\mathbf{0 . 5 3 7 3}$ \\
\hline 5 & $\begin{array}{l}\text { Formulative } \\
\text { (item P\&N) n=16 }\end{array}$ & 0.6553 & $\mathbf{0 . 6 8 8 9}$ & $\mathbf{0 . 7 1 7 2}$ & $\mathbf{0 . 7 5 1 6}$ & $\mathbf{0 . 5 7 6 5}$ & $\mathbf{0 . 6 7 2 7}$ \\
\hline 6 & $\begin{array}{l}\text { Problem solving } \\
\text { (item P\&N) n=12 }\end{array}$ & 0.5692 & $\mathbf{0 . 5 6 5 3}$ & $\mathbf{0 . 5 2 8 8}$ & $\mathbf{0 . 4 5 7 8}$ & $\mathbf{0 . 6 7 2 8}$ & $\mathbf{0 . 5 5 5 3}$ \\
\hline 7 & $\begin{array}{l}\text { Social networking } \\
\text { (item P\&N) n=20 }\end{array}$ & 0.8124 & $\mathbf{0 . 6 0 1 3}$ & $\mathbf{0 . 6 5 7 8}$ & $\mathbf{0 . 6 2 3 1}$ & $\mathbf{0 . 5 4 0 0}$ & $\mathbf{0 . 6 0 5 6}$ \\
\hline 8 & $\begin{array}{l}\text { Business } \\
\text { performance =23 }\end{array}$ & 0.8861 & $\mathbf{0 . 9 3 7 0}$ & $\mathbf{0 . 8 9 1 4}$ & $\mathbf{0 . 8 1 6 2}$ & $\mathbf{0 . 9 5 5 1}$ & $\mathbf{0 . 9 3 7 3}$ \\
\hline
\end{tabular}

Table 1. Test-Retest Results (for draft instrument with 151 items and 5 Likert scales)

in a set of data. It also takes into considerations the size of the sample. The following are the assumptions in doing this procedure:

1. Communality

- Estimate the values of the common variance of each item under on construct (factor) (Field, 2000)

- $\quad$ The values of the communality is between 0-1

- $\quad$ For the sample size less than 100, the communality values is $>0.6$

- For the sample size between 100-200, the communality values is within the range of 0.5

2. Eigen value

- Determine the number of constructs or factors (Kaiser 1974)

- $\quad$ For Eigen values $>1$ or more should be do further test

- Represent the total variance as a whole which is explain by the factor analysis

3. Loading factor

- Determine whether an item is included or not included in a factor

- Provide the correlational values between items in a factor, the bigger the values of the loading factor, the stronger the correlations between the items in a factor

- The method of determining the values of the loading factor depend on the sample size (Guadagnoli \& Velicer 1988)

- $\quad$ The minimum values of the loading factor is 0.3 (William and Monge, 2001

- $\quad$ According to Tabachnick \& Fidel, 2001, loading factor for each sample group:

- $\quad$ Sample >150, loading factor 0.5

- $\quad$ Sample $>150$, loading factor 0.4

- $\quad$ Sample $>300$ loading factor 0.3

4. Finally, the items within these constructs will be tested again for its Cronbach Alpha to double check the internal consistency of the values. 
Construct: Self

\begin{tabular}{|c|c|c|c|c|c|c|c|c|c|c|}
\hline & \multicolumn{10}{|c|}{ Sub-constructs/Factors } \\
\hline Item no. & 1 & 2 & 3 & 4 & 5 & 6 & 7 & 8 & 9 & 10 \\
\hline c111 & .792 & & & & & & & & & \\
\hline c101 & .763 & & & & & & & & & \\
\hline $\mathrm{c} 128$ & .579 & & & & & & & & & \\
\hline c115 & .549 & & & & & & & & & \\
\hline c58 & .502 & & & & & & & & & \\
\hline c91 & & .793 & & & & & & & & \\
\hline$c 85$ & & .774 & & & & & & & & \\
\hline c1 & & .564 & & & & & & & & \\
\hline c121 & & .560 & & & & & & & & \\
\hline \multicolumn{11}{|l|}{ c124 } \\
\hline c119 & & & .800 & & & & & & & \\
\hline $\mathrm{c} 120$ & & & .692 & & & & & & & \\
\hline c3 & & & & .702 & & & & & & \\
\hline c29 & & & & .645 & & & & & & \\
\hline c15 & & & & .540 & & & & & & \\
\hline \multicolumn{11}{|l|}{ c9 } \\
\hline $\mathrm{c4}$ & & & & & .670 & & & & & \\
\hline$c 43$ & & & & & .531 & & & & & \\
\hline c37 & & & & & .519 & & & & & \\
\hline \multicolumn{11}{|l|}{ c65 } \\
\hline \multicolumn{11}{|l|}{ c52 } \\
\hline \multicolumn{11}{|l|}{ c51 } \\
\hline c98 & & & & & & .761 & & & & \\
\hline c99 & & & & & & .563 & & & & \\
\hline c31 & & & & & & .555 & & & & \\
\hline c71 & & & & & & & .718 & & & \\
\hline c79 & & & & & & & .679 & & & \\
\hline \multicolumn{11}{|l|}{$\mathrm{c} 45$} \\
\hline c105 & & & & & & & & .725 & & \\
\hline $\mathrm{c} 23$ & & & & & & & & .571 & & \\
\hline c94 & & & & & & & & & .794 & \\
\hline c87 & & & & & & & & & .516 & \\
\hline c73 & & & & & & & & & & .800 \\
\hline Alpha & 0.788 & 0.762 & 0.783 & 0.496 & 0.405 & 0.500 & 0.520 & 0.382 & 0.339 & $x$ \\
\hline $\begin{array}{l}\text { Eigen } \\
\text { value }\end{array}$ & 7.148 & 2.276 & 2.048 & 1.841 & 1.761 & 1.389 & 1.344 & 1.247 & 1.225 & 1.041 \\
\hline $\begin{array}{l}\text { Explain } \\
\text { variance } \\
(\%)\end{array}$ & 21.661 & 6.896 & 6.205 & 5.580 & 5.337 & 4.209 & 4.074 & 3.777 & 3.712 & 3.153 \\
\hline $\begin{array}{l}\text { Total } \\
\text { Explain } \\
\text { variance } \\
(\%)\end{array}$ & \multicolumn{10}{|c|}{64.606} \\
\hline
\end{tabular}




\section{Construct: Cognitive}

\begin{tabular}{|c|c|c|c|c|c|c|c|c|}
\hline & \multicolumn{8}{|c|}{ Sub-constructs/Factors } \\
\hline Item no. & 1 & 2 & 3 & 4 & 5 & 6 & 7 & 8 \\
\hline c107 & .711 & & & & & & & \\
\hline c54 & .652 & & & & & & & \\
\hline $\mathrm{c} 47$ & & & & & & & & \\
\hline c41 & & .754 & & & & & & \\
\hline c83 & & .588 & & & & & & \\
\hline c5 & & & & & & & & \\
\hline c39 & & & & & & & & \\
\hline c33 & & & .642 & & & & & \\
\hline c20 & & & .611 & & & & & \\
\hline c75 & & & .555 & & & & & \\
\hline c77 & & & & .745 & & & & \\
\hline c60 & & & & .676 & & & & \\
\hline c81 & & & & .527 & & & & \\
\hline c96 & & & & & .692 & & & \\
\hline $\mathrm{c} 89$ & & & & & .621 & & & \\
\hline c67 & & & & & & .747 & & \\
\hline c69 & & & & & & .728 & & \\
\hline c18 & & & & & & & .790 & \\
\hline c11 & & & & & & & .647 & \\
\hline c6 & & & & & & & & .695 \\
\hline c25 & & & & & & & & .607 \\
\hline Alpha & 0.577 & 0.567 & 0.531 & 0.472 & 0.438 & 0.487 & 0.377 & 0.414 \\
\hline $\begin{array}{l}\text { Eigen } \\
\text { value }\end{array}$ & 3.486 & 2.025 & 1.589 & 1.355 & 1.295 & 1.171 & 1.117 & 1.093 \\
\hline $\begin{array}{l}\text { Explain } \\
\text { variance } \\
(\%)\end{array}$ & 16.599 & 9.645 & 7.567 & 6.452 & 6.166 & 5.578 & 5.319 & 5.202 \\
\hline \begin{tabular}{|l} 
Total \\
Explain \\
variance \\
$(\%)$
\end{tabular} & & & & 62. & & & & \\
\hline
\end{tabular}


Constructs: Social Networking

\begin{tabular}{|c|c|c|c|c|}
\hline & \multicolumn{4}{|c|}{ Sub-constructs/Factors } \\
\hline Item no. & 1 & 2 & 3 & 4 \\
\hline c49 & .789 & & & \\
\hline c35 & .732 & & & \\
\hline c103 & & .815 & & \\
\hline c126 & & .714 & & \\
\hline c116 & & .533 & & \\
\hline c56 & & & -.736 & \\
\hline c113 & & & .680 & \\
\hline c109 & .519 & & .577 & \\
\hline c93 & & & & .720 \\
\hline c63 & & & & .701 \\
\hline Alpha & 0.580 & 0.528 & $x$ & 0.193 \\
\hline Eigen value & 2.152 & 1.502 & 1.298 & 1.056 \\
\hline $\begin{array}{l}\text { Explain variance } \\
(\%)\end{array}$ & 21.525 & 15.024 & 12.982 & 10.558 \\
\hline $\begin{array}{l}\text { Total Explain } \\
\text { variance }(\%)\end{array}$ & \multicolumn{4}{|c|}{60.088} \\
\hline
\end{tabular}

Table 2. Factor Analysis Results for Items belong to each construct/factor (Number of respondents $=133$; Loading Factor $=0.5$ )

\section{Factorial Analysis Results for Items Rejected in Each Construct}

Based on the above factorial analysis results of the loading factors of those items less than 0.5 were automatically rejected as listed below. Furthermore, those items that were written in italic were the additional items that were rejected after testing their Cronbach Alpha values once more. Thus, the total number of items rejected based in the draft instrument with 151 items and 5 likert scales were 22 .

\begin{tabular}{|l|l|l|l|l|}
\hline No & Self & Cognitive & Social Networking & \\
\hline 1 & $\begin{array}{l}\text { Optimistic } \\
15,4,43\end{array}$ & $\begin{array}{l}\text { Competence } \\
39, \mathbf{1 1}, \mathbf{1 8}, \mathbf{8 1}\end{array}$ & $113,56, \mathbf{6 3}, 93$ & \\
\hline 2 & $\begin{array}{l}\text { Perseverance } \\
9,23, \mathbf{9 4}, 37\end{array}$ & $\begin{array}{l}\text { Formulative } \\
5,47\end{array}$ & & \\
\hline & Fitness & Problem Solving & & \\
& $45,124,73, \mathbf{1 0 5}, \mathbf{8 7}$ & & & \\
\hline
\end{tabular}

Total items reduction $=22$; Items' Communality $<0.5$; Loading Faktor $<0.5$; Alpha Cronbach $<0.5$; Corrected item-total correlation $<0.3$.

Table 3. The total number of items rejected in the draft instrument with 151 items and 5 likert scales (Number of respondents $=133$; Loading Factor $=0.5$ ) 


\section{Retained items from draft instrument with 151 items and 5 likert scales}

The following is the list of items retained for each construct in the draft instrument with 151 items and and 5 Likert scales which totalled up to 84 items altogether. The number with the sign $\left({ }^{*}\right)$ refers to the negative items.

\begin{tabular}{|l|l|}
\hline OPTIMISTIC (O) 18 item & $1,2^{*}, 9,16^{*}, 17,25,28^{*}, 35,40^{*}, 47,51,52^{*}, 61,64^{*}, 70^{*}, 71,79^{*}, 84^{*}$ \\
\hline $\begin{array}{l}\text { PERSEVERANCE (P) } \\
8 \text { item }\end{array}$ & $3,6^{*}, 11,12^{*}, 22^{*}, 29,46^{*}, 67$ \\
\hline FITNESS (F) 16 item & $4^{*}, 5,10^{*}, 13,19,20^{*}, 21,30^{*}, 31,36^{*}, 43,49^{*}, 56^{*}, 60^{*}, 63,76$ \\
\hline $\begin{array}{l}\text { COMPETENCES(C) } \\
6 \text { item }\end{array}$ & $7,8^{*}, 14^{*}, 15,18^{*}, 23$ \\
\hline $\begin{array}{l}\text { FORMULATIF(FM) 12 } \\
\text { item }\end{array}$ & $24^{*}, 27,32^{*}, 33,38^{*}, 39,42^{*}, 45,50^{*}, 53,62^{*}, 78$ \\
\hline $\begin{array}{l}\text { PROBLEM SOLVING } \\
\text { (PS) 12 item }\end{array}$ & $26^{*}, 34^{*}, 37,48,55,65,68^{*}, 72^{*}, 73,77^{*}, 82^{*}, 83$ \\
\hline $\begin{array}{l}\text { SOCIAL NETWORKING } \\
\text { (SN) 12 item }\end{array}$ & $41,44^{*}, 54^{*}, 57,58^{*}, 59,66^{*}, 69,74^{*}, 75,80^{*}, 81$ \\
\hline Total 84 items & Plus Outcome 23 items \\
\hline
\end{tabular}

Table 4 . List of items retained for each construct in the draft instrument with151 items and and 5 Likert scales

\section{Interpretation of the index level of entrepreneur resilience}

Since the reliability of both the positive and negative items are stable throughout a series of group's administration, three format of the entrepreneur resilience instruments were proposed. The purpose was to provide some flexibility to choose which format suits the need of a particular organization interested in using it. For each format, the index calculation is slightly different. Also for each index level, there is an interpretation of that from the resilience point of view. Finally for each interpretation, there is a recommendation of steps to be taken by the entrepreneurs either to maintain or improve his or her resilience strengths.

Three different format of the entrepreneur resilience instruments were proposed based on the level of recommendation and reasons for them (Table 3).

\section{Interpretation and intervention of the resilience index scores}

\section{Low scores: Range between lowest and lower middle}

A self-rating score within this range indicates that business is probably a struggle for the entrepreneur and he/she knows it. He/she may not handle the business pressure well. $\mathrm{He} /$ she don't learn anything useful from bad experiences. He/she feels hurt when people criticize him/her. He/she may sometimes feel helpless and without hope.

\section{Intervention proposed}

If an entrepreneur scored within this range, he/she should ask this question for him/herself "Would I like to learn to handle my difficulties better?" If the answer is yes, then a good 


\begin{tabular}{|l|l|l|l|}
\hline 1 & Format & Choice & Reasons \\
\hline 1 & $\begin{array}{l}\text { Instrument A: 42 resilient items altogether } \\
\text { (replaced some items with the non- } \\
\text { resilience items for the purpose of lie } \\
\text { detectors) plus the 23 resilience outcome } \\
\text { items } \\
\text { (Total items: 65) }\end{array}$ & First & $\begin{array}{l}\text { Respondents will feel } \\
\text { most comfortable } \\
\text { because the number of } \\
\text { items are just moderate. } \\
\text { In addition, it also } \\
\text { includes the outcomes } \\
\text { of the resilient attitude } \\
\text { in terms of perceptive } \\
\text { performance. }\end{array}$ \\
\hline 2 & $\begin{array}{l}\text { Instrument B: 42 resilience items + 42 non } \\
\text { resilience items and 23 resilient outcomes } \\
\text { items } \\
\text { (Total items: 107) }\end{array}$ & $\begin{array}{l}\text { Second } \\
\text { tired to answer a lot of } \\
\text { items and this might } \\
\text { influence their honesty, } \\
\text { thus the results of the } \\
\text { measure. However, it } \\
\text { can measure both the } \\
\text { resilience and non- } \\
\text { resilience level }\end{array}$ \\
\hline 3 & $\begin{array}{l}\text { Instrument C: 42 resilience items } \\
\text { altogether (replaced some items with the } \\
\text { non-resilience items for the purpose of lie } \\
\text { detectors) but without the outcome items } \\
\text { (Total items: 42) }\end{array}$ & $\begin{array}{l}\text { Even though the } \\
\text { number of items are the } \\
\text { least compared to the } \\
\text { above two but the } \\
\text { outcomes of the } \\
\text { resilience in terms of } \\
\text { perceptive performance } \\
\text { are not included. }\end{array}$ \\
\hline
\end{tabular}

Table 5. Format of the entrepreneur resilience instruments, the level of recommendation and reasons for them.

way to start is to meet with other entrepreneurs/entrepreneurs who are working to develop their resiliency skills. Let them coach, encourage and guide you. Another way, is to get resiliency coaching from a trained business counsellor. The fact that the concerned entrepreneur feel motivated to be more resilient is a positive sign.

\section{High scores: At the highest level}

High scores: A self-rating score within this range indicates the entrepreneur is taking up the business challenges very well. This means he/she is already very good at bouncing back from business setbacks. He/she has taken the right steps and strategies to sustain his/her business. He/she also likes learning new ways to be even better which will take his/her already good skills to even a much higher level-something like reaching to the advanced level of business growth.

\section{Suggestion proposed:}

If anentrepreneur scored within this range, he/she should ask this question for him/herself "Would I like to share and make myself available to other entrepreneurs who are trying to cope with business difficulties?" He/she should be a real life role model for them. 


\section{Middle scores: Range between middle and upper middle}

Middle scores: A self-rating score within this range indicates the entrepreneur is taking up some (not all) of the business challenges very well. Once in a while he/she might have some difficulties but able to bounce back after some time with some hard work or struggles.

Notes for administrator to consider:

Being a middle scorers, he/she might underrate him/herself than overrate him/herself. Some people have a habit of being modest and automatically give themselves a 3 on every item for a total of middle scores. Thus, if he/she is a middle scorer, we need to find out how valid is their self-rating is. One way, is to ask two people who know he/she well to rate him/her on the items and see what scores they come up with. Have a discussion with them about each of the items where there is a discrepancy and listen to what they say. If they rate him/her higher, then the entrepreneur has a good resilience level.

\section{Intervention proposed:}

If anentrepreneur scored within this range, he/she should ask this question for him/herself, "Would I like to fight harder to achieve excellence in my business?". If the answer is yes, then a good way to start Is to model other entrepreneurs who had developed their resiliency skills and become successful. Learn about them and follow their steps. Another way, is to develop a networking with them and let them inspire you.

\section{The use of resilience outcomes level}

The purpose of having to measure the level of perceptive business performance is to find out if the psychological based resilience level of the entrepreneur is parallel with it. The point is some entrepreneur thinks he or she is resilient but the fact is his or her perceptive business performance is not doing very well. Thus, some other reasons for the difference should be looked into. These reasons could be uncontrollable factors such as changing in trends, policy, unexpected natural disasters and family incidences. On the other hand, it could be the business knowledge and skills factors of the entrepreneurs.

\section{Implementation of the instrument}

This instrument should be administered on the new entrepreneurs who have started their businesses between 1-3 years. Most experts also agreed that these are the number of thriving years that entrepreneurs usually have to strive before reaching the stage of clearly firm with their stand to stay in the business regardless of any obstacle they would face from time to time. In addition, the stage where they are willing to face any challenge that come in their way towards success.

\section{Conclusion}

Based on the resilience index and its interpretations, entrepreneurs can think of what are the necessary resilience training interventions to take for the purpose of sustaining their businesses.

\section{i. Resilience Training}

Resilience is a critical personal competency for individuals who wish to re-ignite their careers, succeed under sustained pressure; quickly recover from work, health or relationship 
setbacks and full fill their life goals. Equally, resilience has become a key strategic competence for organizations that want to attract, retain and motivate great people. Entrepreneur who have a resilient disposition are better able to maintain poise and a healthy level of physical and psychological wellness in the face of business's challenges. Entrepreneur who are less resilient are more likely to dwell on problems, feel overwhelmed, use unhealthy coping tactics to handle stress, and develop anxiety and depression. Resiliency can be developed by learning and practicing mindfulness and other mind-body techniques. Mindfulness helps them achieve an elevated sense of awareness by consciously recognizing and accepting the present. It brings purposeful, trained attention out of the negative thoughts of the mind and into the reality of the world in the present moment.

Forming a resilient disposition entails:

- Fostering acceptance

- $\quad$ Finding meaning in life career

- Developing gratitude

- Addressing spirituality

- Retraining one's attention

A resilient approach leads to addressing problems rather than avoiding them, a positive, optimistic outlook and a flexible, adaptive disposition. Research has shown that these techniques engage the prefrontal cortex, the part of the brain that regulates emotion, thinking and behaviour. Resilience training empowers individuals to change unconstructive behaviours, actions and ways of thinking. Training helps new entrepreneur develop four types of resilience to lead a more balanced and healthier life as a businessman;

- Cognitive - preserving attention, memory, judgment and problem-solving skills.

- Physical - maintaining well-being through regular exercise, a healthy diet and restful sleep.

- Emotional - approaching life career with a realistic, balanced and flexible disposition and addressing rather than avoiding problems.

- Spiritual - practicing and keeping in mind the concepts of forgiveness, acceptance, compassion, true meaning and purpose.

The following are proposed topics for resilience training interventions of the new entrepreneur

\section{Resilient Organization Training}

This training helpentrepreneurs to build a resilient organization. A resilient organisation is calm, energised, engaged, focused and purposeful. Leaders and workers cultivate health, happiness and productivity. This attracts, retains and motivates all stakeholders. A Resilient organisation is one which realises its own potential through nurturing the ability of those working within it to i) Bounce back from adversity, ii) Thrive on challenge iii) Explore and reach their own full potential and iv) Have a positive impact on others. Resilience interventions systematically extract the benefits of stress management, individual and corporate health, emotional intelligence and thinking skills. Language, practical skills and creative frameworks become part of organisational culture - one which respects and honours the combined potential of body, heart, mind and spirit. 
2. Resilient entrepreneurs training

Entrepreneurs can also attend resilient training based on needs. The content of the resilient training for entrepreneurs should cover the 6 core skills such as:

1. Optimism based on changing mindset towards business which changes way oftackling projects, erases negative thought patterns and depression.

2. Regulating emotions to perform at optimum levels under stress.

3. Engage in effective relationships.

4. Problem solving techniques.

5. Personal resilience techniques.

6. Managing staff in a pressurised fast paced environment

\section{Appendix}

\section{The sample instrument}

\section{Instruction}

The Please tick $(\sqrt{ })$, write or circle your answer where appropriate.

Your answers are very important to the accuracy of this study.

(Please return the completed questionnaire in the enclosed self-addressed envelope at your earliest convenience.)

\section{No Item}

1 I have a strong sense of vision to succeed that keep myself going

2 I tolerate the pressure to grow my business further within the limited resources

3 I am always clear what to do regardless of the business problems I have.

4 I usually formulate a series of steps to close the gap between the current position of my business and the desired goal

5 I can accept failures as part of the learning process in business

6 I believe in working not more than eight hours a day regardless of how much work to do

7 I will feel comfortable if work tasks are clearly defined

8 I believe customers have to adapt to my product

9 I know when the time is right to act when change in strategy is inevitable

10 I usually finish my work task

\begin{tabular}{|c|c|c|c|c|}
\hline $\begin{array}{l}\text { Strongly } \\
\text { Disagree }\end{array}$ & $\begin{array}{c}\text { Dis } \\
\text { agree }\end{array}$ & $\begin{array}{c}\text { Less } \\
\text { Agree }\end{array}$ & Agree & $\begin{array}{c}\text { Strongly } \\
\text { Agree }\end{array}$ \\
\hline 1 & 2 & 3 & 4 & 5 \\
\hline 1 & 2 & 3 & 4 & 5 \\
\hline 1 & 2 & 3 & 4 & 5 \\
\hline 1 & 2 & 3 & 4 & 5 \\
\hline 1 & 2 & 3 & 4 & 5 \\
\hline 1 & 2 & 3 & 4 & 5 \\
\hline 1 & 2 & 3 & 4 & 5 \\
\hline 1 & 2 & 3 & 4 & 5 \\
\hline 1 & 2 & 3 & 4 & 5 \\
\hline 1 & 2 & 3 & 4 & 5 \\
\hline
\end{tabular}


No Item

adequately and on schedule

11 I am healthy and fit most of the time since I run my business

12 I keep studying the market trend of my product(s) to adjust my strategy

13 I tolerate ambiguity of what I should do to achieve my business goal

14 I do a lot of brainstorming with my partner(s) or staff(s) to formulate creative idea(s)

15 I manage change in my business organization by taking one step at a time

Saya menangani perubahan dalam perniagaan dengan mengambil satu langkah pada satu masa

16 I can accept sudden heavy workload in the last minute (i.e. customers' order; project's change of timelines, etc)

17 I make a point to learn from different cases of problems

18 I even become more strongly motivated if I have not yet achieved success

19 I do not automatically accept what I see and hear about my business

20 I work fast by organizing my business activities according to priorities and timelines

21 I believe in working as a team with my business partner(s) or staff(s) to accomplish a task

22 I don't allow myself get stucked by keep looking to the future of my business

23 I accept my client's comments to improve my product(s)

24 I enjoy the feeling of autonomy to steer my business towards success

25 I evaluate all new evidences that come with my business problem(s)
Strongly Dis Less

Disagree agree

Agree

Strongly

Agree Agree

1

1

2

3

4

5

2

34

5

1

2

34

5

1

2

34

5

1

2

3

4

5

1

2

3

4

5

1

2

3

4

5

1

2

3

4

5

1

2

3

4

1

2

34

1

2

34

1

2

3

4

1

2

3

4

1

2

3

4

5

1

2

3

4 
No Item

26 Once I have set out on the path to solution, I follow through it myself till end

27 I feel intrinsically rewarded when I can solve a problem

28 I hand over to someone I trust to handle my staff(s)'s work problems

29 I gather relevant and up-to-date information of an issue before taking a position

30 I can accept other people's views for my business

31 I keep giving assistance or encouragement to deepen social support to my staff(s) when resolving conflicts

32 I am affected when my client(s) express their feelings of dissatisfaction

33 I feel that I cannot keep up with the current needs of my business to expand

34 I rely heavily on my staff(s) to report on the sales performance

35 I am very capable of adapting to change in my business

environment

(i.e. resource supply, government policy, cost of materials, consumers' trend, loss of good employees etc)

36 I tell my feelings of doubts to my business partner(s) or staff(s)

37 I wonder if I have the capability to sustain my business

38 I search for information on how to strategically allocate my limited resources for efficiency

(i.e. time, money, equipment, space etc)

39 I have to think of myself during critical times and let my staffs take care of themselves

40 I am willing to spend my time and energy to help my business partner(s) or staff(s) in need

\section{Strongly Dis Less \\ Disagree agree Agree Agree Agree}

1

1

2

3

4

5

2

3

4

5

1

2

3

4

5

1

2

3

4

5

1

2

3

4

5

1

2

3

4

5

1

2

3

4

5

1

2

3

4

5

1

2

3

4

5

1

2

3

4

5

1

1

2

3

4

1

2

3

4

5

1

2

3

4

1

2

3

4

1

2

3

4 
No Item

41 I have a lot of stamina almost every day since I run my business

42 I persist discussing with my partner(s) on any decision even though its difficult

\section{Section 2}

\section{No Item}

1 Overall, the performance of my business is getting better each year

2 The returns of my business is increasing each year.

3 The cost of running my business is still reasonable

4 The turnover growth of my business is better each year

5 The number of personnel in my business is still manageable.

6 The financial risks of my business is still within my control

7 There is a possibility of earning more income from new opportunities that my business had identified.

8 I can see that my business is thriving very well

9 The number of clients is adding up from time to time due to my business product(s)'s quality

10 The speed of development of my business is suitable with the effort that I had put in

11 My business has a good potential to grow and sustain in the future

12 I am comfortable with the time span that I had used to bring my business to a more stable stage

13 I accept the fact that there is a cost to any decision that I take in my business activities

14 I am able to ignore my fear of failure and future results to continue working hard for my business

15 I can always figure out how to solve problems that arise at my

$\begin{array}{ccccc}\begin{array}{c}\text { Strongly } \\ \text { Disagree }\end{array} & \begin{array}{c}\text { Dis } \\ \text { agree }\end{array} & \begin{array}{c}\text { Less } \\ \text { Agree }\end{array} & \begin{array}{c}\text { Strongly } \\ \text { Agree }\end{array} & \begin{array}{c}\text { Agree } \\ 1\end{array} \\ 2 & 3 & 4 & 5 \\ 1 & 2 & 3 & 4 & 5\end{array}$

\section{Strongly Less}

Disagree Disagree Agree Agree Agree

$\begin{array}{lllll}1 & 2 & 3 & 4 & 5 \\ 1 & 2 & 3 & 4 & 5 \\ 1 & 2 & 3 & 4 & 5 \\ 1 & 2 & 3 & 4 & 5 \\ 1 & 2 & 3 & 4 & 5 \\ 1 & 2 & 3 & 4 & 5\end{array}$

1

2

34

5

1

1

2

3

4

5

1

2

3

4

5

1

2

3

4

5

1

2

3

4

5

1

2

3

4

5

1

2

3

4

5

1

2

3

4 
No Item

business place

16 I don't let myself neglect the daily running of business even though preoccupied with many problems

17 I can take advantage of the changing environment to my benefit

18 I respond to adverse situations in my business with positive attitude

19 I am able to handle many conflicting decisions in my business with patience

20 I don't act impulsively whenever I face with stressful moments with my clients and staff(s)

21 I react constructively to stressful situations in my daily running of business Saya bertindak secara konstruktif dalam situasi yang tertekan semasa

22 I manage to see and capitalize on the opportunity that come with change in my business environment

23 I courageously face potentially disruptive changes by turning adversity into advantageous opportunity

\section{Strongly Less \\ Disagree Disagree Agree Agree Agree \\ Strongly}

$\begin{array}{lllll}1 & 2 & 3 & 4 & 5 \\ 1 & 2 & 3 & 4 & 5\end{array}$

1

2

34

5

1

2

34

5

1

2

34

5

1

2

3

4

5

1

2

3

4

5

1

2

3

4

5

\section{References}

Baron, R., Frese, M., and Baum, J.R. (2007).The Psychology of Entrepreneurship. New Jersey: Lawrence Erlbaum Associates Inc.

Benson, J., \& Clark, F. (1983).A guide for instrument development and validation.American Journal of OccupationalTherapy, 36, 789-800.

Brooke R. (2004). Beyond Human and Social Capital.Proceedings of the Academy of Entrepreneurship.10(2) May.

Carver, C.S., Sutton, S.K., \&Scheier, M.K. (2000). Action, emotion and personality: Emerging conceptual integration. Personality and Social Psychology Bulletin, 26, 741-751.

Creswell, J.W. (2008)Educational Research: Planning, conducting and evaluatingquantitative and qualitative research Ed. Ke-2. Upper Saddle River, NJ: Pearson Education Inc./Merril Prentice Hall.

Davidson, R. J. (2000). "Affective style, psychopathology, and resilience: Brain mechanisms and plasticity". American Psychologist55 (11): 1196-1214. 
Gall, M. D., Gall, J. P., \& Borg, W. R. 2003.Education research: An introduction.Edisi ke-7. Boston: Pearson education, Inc.

Guadagnoli, E. \&Velicer, W. F. (1988).Relation of sample size to the stability of component patterns.Psychological Bulletin, 103, 265-275.

Luthar, S. S., Cicchetti, D., Becker, B. (2000)."The Construct of Resilience: A Critical Evaluation and Guidelines for Future Work". Child Development71 (3): 543-562.

Luthans, F. (2004) Positive psychological capital.Business Horizons.47 (1) : 45-50.

Malaysia Multimedia Development Corporation (MdeC). (2009). Technopreneur Resilience Report.

Masten, A. S. (1989). Resilience in development: Implications of the study of successful adaptation for developmental psychopathology. In D. Cicchetti (Ed.), The emergence of a discipline: Rochester symposium on developmental psychopathology (Vol. 1, pp. 261294). Hillsdale, NJ: Erlbaum.

Masten A, Best K, Garmezy N. Resilience and development: Contributions from the study of children who overcome adversity. Development and Psychopathology.1990;2:425-444.

Nandram, S. S. \& Samson, K. J. 2006.The spirit of entrepreneurship.Heidelberg: Springer.

Tabachnick, B. G., \& Fidell, L. S. (2001).Using multivariate statistics (4th ed.). Needham Heights, MA: Allyn\& Bacon.

Werner, E.E. \& Smith, R.S. (2001). Journeys from childhood to midlife: Risk, resiliency, and recovery. Ithaca, NY: Cornell University Press.

William, F. \&Monge, P. (2001). Reasoning with statistics: How to read Quantitative Research. American Communication Journal, 5(2) 544-556. 


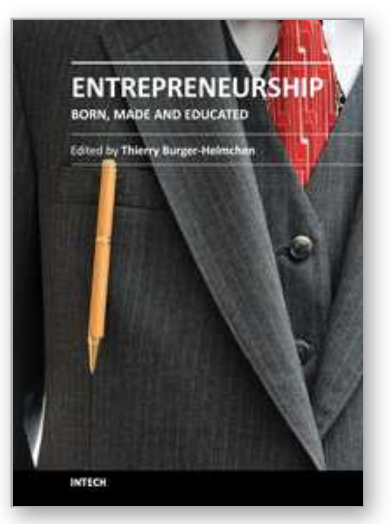

\author{
Entrepreneurship - Born, Made and Educated \\ Edited by Prof. Thierry Burger-Helmchen
}

ISBN 978-953-51-0210-6

Hard cover, 336 pages

Publisher InTech

Published online 14, March, 2012

Published in print edition March, 2012

Entrepreneurship has a tremendous impact on the economic development of a country. As can be expected, many public policies foster the development of self- entrepreneurship in times of unemployment, praise the creation of firms and con- sider the willingness to start new ventures as a sign of good fortune. Are those behaviours inherent to a human being, to his genetic code, his psychology or can students, younger children or even adults be taught to become entrepreneurs? What should be the position of universities, of policy makers and how much does it matter for a country? This book presents several articles, following different research approaches to answer those difficult questions. The researchers explore in particular the psychology of entrepreneurship, the role of academia and the macroeconomic impact of entrepreneurship.

\title{
How to reference
}

In order to correctly reference this scholarly work, feel free to copy and paste the following:

Nor Aishah Buang (2012). Entrepreneurs' Resilience Measurement, Entrepreneurship - Born, Made and Educated, Prof. Thierry Burger-Helmchen (Ed.), ISBN: 978-953-51-0210-6, InTech, Available from: http://www.intechopen.com/books/entrepreneurship-born-made-and-educated/entrepreneurs-resiliencemeasurement

\section{INTECH}

open science | open minds

\section{InTech Europe}

University Campus STeP Ri

Slavka Krautzeka 83/A

51000 Rijeka, Croatia

Phone: +385 (51) 770447

Fax: +385 (51) 686166

www.intechopen.com

\section{InTech China}

Unit 405, Office Block, Hotel Equatorial Shanghai

No.65, Yan An Road (West), Shanghai, 200040, China

中国上海市延安西路65号上海国际贵都大饭店办公楼 405 单元

Phone: +86-21-62489820

Fax: +86-21-62489821 
(C) 2012 The Author(s). Licensee IntechOpen. This is an open access article distributed under the terms of the Creative Commons Attribution 3.0 License, which permits unrestricted use, distribution, and reproduction in any medium, provided the original work is properly cited. 